\title{
Combined Effects of Different Processing Methods on Vitamins and Antinutrients Contents of Pigeon Pea (Cajanus Cajan)Flour
}

\author{
Nwanekezi, E. C., Ehirim, F. N. and Arukwe, D. C.* \\ ${ }^{I}$ Department of Food Science and Technology, Imo State University, Owerri, Nigeria.
}

\begin{abstract}
Combined effects of different processing methods on the vitamins and anti-nutrients contents of pigeon pea were investigated. The pigeon pea seeds were soaked $\left(S_{o} P P F\right)$ i.e., control, soaked and boiled $\left(S_{o} B P P F\right)$, soaked and fermented $\left(S_{o} F P P F\right)$, soaked, boiled and fermented $\left(S_{o} B F P P F\right)$, soaked and sprouted $\left(S_{o} S_{P} P P F\right)$, soaked, sprouted and boiled $\left(S_{0} S_{p} B P P F\right)$, soaked, sprouted and fermented $\left(S_{o} S_{p} F P P F\right)$ and soaked, sprouted, boiled and fermented $\left(S_{0} S_{p} B F P P F\right)$. The vitamins analyzed significantly $(p<0.05)$ increased for sprouted and fermented samples and increased tremendously for combined sprouted/fermented samples with values for vitamins A $0.038-0.077 \mathrm{ug} / 100 \mathrm{~g}, C 2.515-13.820 \mathrm{mg} / 100 \mathrm{~g}, B_{1} 0.730-1.165 \mathrm{mg} / 100 \mathrm{~g}, B_{2} 0.145-$ $0.665 \mathrm{mg} / 100 \mathrm{~g}$ and $B_{3} 2.920-6.510 \mathrm{mg} / 100 \mathrm{~g}$ respectively. The boiled processes recorded decreased vitamin contents. The results equally showed that the oligosaccharides (raffinose and stachyose) contents were reduced by the processing methods with the combined sprouting/fermentation processes recording the highest reduction. The anti-nutrients analyzed were saponins, phytic acids, oxalates, alkaloids, cyanides, trypsin inhibitors, haemagglutinins and tannins and they were reduced by all the processing methods used with the combined sprouting/fermentation $\left(S_{o} S_{p} B F P P F\right.$ and $\left.S_{o} S_{p} F P P F\right)$ effecting the highest reduction of the anti-nutrients.
\end{abstract}

Keywords: Combined effects, different processing methods, vitamins, oligosaccharides, anti-nutrients.

\section{Introduction}

Legume is a term applied broadly to all plants of pea and bean family, botanically referred to as leguminosae or fabaceae (Elegbede, 1998). Legumes are known to be the third largest family among the flowering plants consisting of approximately 650 genera and 20,000 species (Doyle, 1994).Pigeon pea (Cajanus cajan) is a perennial legume grown for food. It is cultivated at subsistence level in Nigeria. Pigeon pea is commonly called fio-fio in Anambra State (Igbo speaking) part of Nigeria (Enwere, 1998). Vitamins are organic substances that can be found in plants or chemically synthesized in animals, which are required in trace amounts for health, growth and reproduction. When ingested by animals, most of them as the active vitamins or provitamins are modified into co-enzymes that act in concert with enzymes to catalyze biochemical reactions (Zubay, 1993). The scientific evidence supporting the important role of vitamins in promoting health and preventing non-communicable diseases, independent of other nutritional constituents, has been stressed (Blunberg, 1995). Vitamins essential for human are classified into fat-soluble (Vitamins A, D, E and K), and water-soluble (Vitamins of the B group and vitamin C).

Anti-nutritional factors in food legumes are chemical substances present in products, although nontoxic but generate adverse physiological responses in animals or humans that consume them. In most cases, antinutritional factors interfere with the utilization of nutrients in legume products (Nwokolo, 1996) and their presence could cause flatulence. Anti-nutritional factors such as proteases (trypsin and chymotrypsin) inhibitors, amylase inhibitors and polyphenols which are a known problem in most legumes are less problematic in pigeon pea than soybean, peas and field beans (Farris and Singh, 1990). Within pigeon pea cultivars, anti-nutritional factors are mainly found among dark-seeded genotypes (Farris and Singh, 1990) that are typically grown in Asia. The native African pigeon pea types are largely cream or white seeded with relatively less anti-nutritional factors.

The anti-nutritional factors found in pigeon pea include trypsin inhibitors, chymotrypsin inhibitors, amylase inhibitors, hemagglutinins (lectins), tannins (polyphenols), saponins, cyanide, phytic acid, oxalate (Farris and Singh, 1990; Nwosu., 2013). Trypsin and chymotrysin inhibitors affect the digestibility of legume proteins while other anti-nutritional factors like tannins, phytates, cyanide and hemagglutinins impart bitter or unacceptable taste to the legumes, causing decreased protein digestibility and absorption of divalent metal ions such as $\mathrm{Fe}^{2+}, \mathrm{Zn}^{2+}$ in the intestine (Abdu et al.,2008). These anti-nutritional factors can be removed by different processing methods like cooking, soaking, sprouting, fermentation, etc. (Adeparasi, 1994).

Some researchers (Henry and Massey, 2001; Oluwole and Taiwo, 2009) have studied the effects of processing methods like soaking, boiling, fermentation, sprouting or germination or maltingon the toxic factors and anti- 
nutrients in legumes. But information on combined effects of different processing methods on the vitamins and anti-nutrients composition of pigeon pea has not been reported hence this study.

\section{Materials And Methods}

\section{MATERIALS COLLECTIION}

The pigeon pea (Cajanus cajan) seeds for this research were purchased from a market (Ahia ohuu) in Aba, Abia State. The chemicals used were obtained from Food Science and Technology laboratory, Imo State University, Owerri and National Root Crops Research Institute, Umudike, Umuahia.

\section{SAMPLE PREPARATION}

Sixteen kilograms of pigeon pea seeds were sorted to remove dirt and other foreign particles after which they were washed. The grains were then soaked in water for 3 hours using a large container and the water drained.

Production of Soaked pigeon pea flour (control): Two (2) kilograms of the soaked grains were dehulled and dried in an oven at $60^{\circ} \mathrm{C}$ for 7 hours. The dried seeds were milled into flour using disc attrition mill (Asiko All, Addis Nigeria). The flour was then sieved with standard sieve (1.0mm mesh) and packaged in polyethylene bag for further studies.

Production of Soaked and Boiled pigeon pea flour: Two (2) kilograms of the soaked grains were dehulled and boiled in water for 1 hour at $100^{\circ} \mathrm{C}$. The water was drained and the seeds dried in an oven at $60^{\circ} \mathrm{C}$ for 7 hours. The dried seeds were milled into flour using disc attrition mill (Asiko All, Addis Nigeria). The flour was then sieved with standard sieve (1.0mm mesh) and packaged in polyethylene bag for further studies.

Production of Soaked and Fermented pigeon pea flour:Two (2) kilograms of the soaked grains were dehulled, crushed, wrapped in plantain leaves and allowed to ferment for 4 days. After fermentation, the grains were dried in an oven at $60^{\circ} \mathrm{C}$ for 7 hours. The fermented dried cotyledons were milled into flour with disc attrition mill (Asiko All, Addis Nigeria) and standard 1.0mm mesh sieved before packaging in polyethylene bag for further studies.

Production of Soaked, Boiled and Fermented pigeon pea flour: Two (2) kilograms of the soaked grains were boiled with water for 1 hour and the water drained. The grains were wrapped in plantain leaves and allowed to ferment for 4 days as described by Ikemefuna (1998). After fermentation, the seeds were dehulled and dried in an oven at $60 \mathrm{C}$ for 7 hours. The dried seeds were milled into flour using disc attrition mill (Asiko All, Addis Nigeria). The legume flour were sieved with standard sieve (1.0mm mesh) and packaged in polyethylene bag for further studies.

Production of Soaked and Sprouted pigeon pea flour: Sprouting was carried out according to the method described by Ariahu et al. (1999). Eight (8) kilograms of the soaked grains were spread in a single layer on a moistened jute bag and allowed to germinate (sprout) at room temperature for 3 days. During this time, the grains were sprayed with water at intervals of 12 hours until the last day of sprouting. After sprouting, the seeds were dehulled and rootlets removed. Then the cotyledons were divided into four portions of $2 \mathrm{~kg}$ each. Then the portion $(2 \mathrm{~kg})$ for the production of soaked and sprouted pigeon pea flour were dried in an oven at $60^{\circ} \mathrm{C}$ for 7 hours and milled into flour using a disc attrition mill (Asiko All, Addis Nigeria) and $1.0 \mathrm{~mm}$ mesh sieved before packaging into polyethylene bag for further studies.

Production of Soaked, Sprouted and Boiled Pigeon Pea Flour: Two (2) kilograms of the sprouted pigeon pea seeds were boiled for 1 hour with water at $100^{\circ} \mathrm{C}$, drained and dried in an oven at $60^{\circ} \mathrm{C}$ for 7 hours. The dried sprouted boiled cotyledons were milled with disc attrition mill (Asiko All, Addis Nigeria), sieved with standard sieve (1.0mm mesh) and packaged in polyethylene bag for further studies.

Production of Soaked, Sprouted and Fermented Pigeon Pea Flour: Two (2) kilograms of the sprouted dehulled grains were wrapped in plantain leaves and allowed to ferment for 4 days as described by Ikemefuna (1998). After fermentation, the cotyledons were dried in an oven at 60C for 7 hours and milled into flour with disc attrition mill (Asiko A11, Addis Nigeria) and standard 1.0mm mesh sieved before packaging in polyethylene bag for further studies.

Production of Soaked, Sprouted, Boiled and Fermented Pigeon Pea Flour: Two (2) kilograms of the sprouted dehulled grains were boiled in water for 1 hour at $100^{\circ} \mathrm{C}$ and the water drained. The sprouted, dehulled and boiled cotyledons were wrapped in plantain leaves and allowed to ferment for 4 days as described by Ikemefuna (1998). After fermentation, the cotyledons were dried in an oven at $60^{\circ} \mathrm{C}$ for 7 hours. The dried sprouted-boiled-fermented grains were milled into flour with disc attrition mill (Asiko All, Addis Nigeria) and standard 1.0mm mesh sieved before packaging in polyethylene bag for further studies.

\section{DETERMINATION OF ANTI-NUTRITIONAL FACTORS.}

Tannins: This was determined by Folin Denis colometric method. Five grams $(5 \mathrm{~g})$ of each sample was put inside a volumetric flask and $50 \mathrm{ml}$ of distilled water dispensed inside the volumetric flask. The mixture was shaken for 30 minutes at room temperature and filtered to obtain the extract. Two millilitres (2ml) of standard tannic acid solution and equal volume of distilled water was dispensed into a separate $50 \mathrm{ml}$ volumetric flask to 
serve as a standard and reagent blank respectively. Then $2 \mathrm{ml}$ of each sample extract was put in their respective labelled flasks. The content of each flask was mixed with $35 \mathrm{ml}$ distilled water and $1 \mathrm{ml}$ of the Folin Denis reagent was added to each. This was followed by $2.5 \mathrm{ml}$ of saturated $\mathrm{Na}_{2} \mathrm{CO}_{3}$ solution. Then each flask was diluted to the $50 \mathrm{ml}$ mark with distilled water and incubated for $90 \mathrm{~min}$ at room temperature. Their absorbances were measured at $760 \mathrm{~mm}$ in a spectrophotometer (Atomic Absorption Spectrophotometer - AAS Model SP9) with the reagent blank at zero.

The tannin content was calculated as:

$\%$ Tannin $=\frac{100}{W} \times \frac{a u}{a s} \times c \times \frac{v t}{v a}$

Where: $\mathrm{W}=$ weight of sample, $\mathrm{au}=$ absorbance of test sample, as $=$ absorbance of standard tannin solution, $\mathrm{c}=$ concentration of standard tannin solution, vt = total volume of extract, va = volume of extract analysed

Saponins: This was done by the double solvent extraction gravimetric method (Harborne, 1973). Five (5) grams of each sample was mixed with $50 \mathrm{ml}$ of $20 \%$ aqueous ethanol solution and incubated for 12 hours at $55^{\circ} \mathrm{C}$ with constant agitation. After that, the mixture was filtered through Whatman No. 42 grades of filter paper. The residue was re-extracted with $50 \mathrm{ml}$ of the ethanol solution for $30 \mathrm{~min}$ and the extracts combined and weighed together. The combined extract was reduced to about $40 \mathrm{ml}$ by evaporation and then transferred to a separating funnel and equal volume $(40 \mathrm{ml})$ of diethyl ether was added to it. After mixing well, there was a partition and the upper layer of the partition was discarded while the aqueous layer was reserved. This aqueous layer was reextracted with the ether after which its $\mathrm{pH}$ reduced to 4.5 with drop-wise addition of dilute $\mathrm{NaOH}$ solution. Saponin in the extract was taken up in successive extraction with $60 \mathrm{ml}$ and $30 \mathrm{ml}$ portion of normal butanol. The combine extracts was washed with $5 \% \mathrm{NaCl}$ solution and evaporated to dryness in a previously weighed evaporating dish. The saponin was then dried in the oven at $60^{\circ} \mathrm{C}$ (to remove any residual solvent), cooled in a desiccator and reweighed. The saponin was determined and calculated as percentage of the original samples.

$\%$ Saponin $=\frac{W 2-W 1}{W} \times 100$

Where: $\mathrm{W}=$ weight of sample used

$\mathrm{W}_{1}=$ weight of empty evaporating dish

$\mathrm{W}_{2}=$ weight of dish + saponin extract

Alkaloids: The alkaline precipitation gravimetric method (Harborne, 1973) was used. Five (5) grams of each sample was dispersed in $100 \mathrm{ml}$ of $10 \%$ acetic acid in ethanol solution. The mixture was well shaken and allowed to stand for 4 hours at room temperature and shaken every 30 minutes. At the end of this period, the mixture was filtered through Whatman No. 42 filter paper. The filtrate (extract) was concentrated by evaporation to a quarter of its original volume. The extract was treated with drop-wise addition of concentrated $\mathrm{NH}_{3}$ solution to precipitate the alkaloid. The dilution was done until the $\mathrm{NH}_{3}$ was in excess. The alkaloid precipitate was removed by filtration using weighed Whatman No. 42 filter paper. The paper was dried at $60^{\circ} \mathrm{C}$ and re-weighed after cooling in a desiccator. The weight of alkaloid was determined and expressed as a percentage of the sample.

$\%$ Alkaloid $=\frac{W 2-W 1}{\text { Weight of sample }} \times 100$

Where: $\quad \mathrm{W}_{1}=$ weight of empty filter paper

$\mathrm{W}_{2}=$ weight of filter paper + alkaloid precipitate

Cyanide: The cyanide contents of the samples were determined using the method described by Bradbury et al. (1985). Five (5) grams of each sample was dissolved in 50ml distilled water in a corked conical flask to extract cyanide. The cyanide extraction was allowed to run overnight. The extract was filtered through a filter paper. Alkaline picrate solution was prepared by dissolving $1 \mathrm{~g}$ of picric acid and $5 \mathrm{~g}$ of sodium carbonate in warm water in a volumetric flask and the volume made up to $200 \mathrm{ml}$ with distilled water. To $1 \mathrm{ml}$ of the sample filtrate was added $4 \mathrm{ml}$ alkaline picrate and this was incubated in water bath for 5 minutes for colour development. After the development of the reddish brown colour, the absorbance of the solution was read at 490nm on a spectrophotometer. The absorbance of a blank containing $1 \mathrm{ml}$ distilled water and $4 \mathrm{ml}$ alkaline picrate solution was also read. Standard cyanide solution was prepared from different concentrations of potassium cyanide solution containing 5 to $50 \mu \mathrm{g}$ cyanide in a $500 \mathrm{ml}$ conical flask, $25 \mathrm{ml}$ of $1 \mathrm{~N} \mathrm{HCl}$ was added. The experiment was carried out in triplicates. Cyanide was expressed as mg per kilogram of the sample.

$\mathrm{HCN}(\mathrm{mg} / \mathrm{kg})=1000 \times 0.05 \times W \times \frac{a u}{a s}$

Where: $\mathrm{W}=$ weight of sample

$\mathrm{au}=$ absorbance of the test sample

as $=$ absorbance of standard solution

Phytate: Phytate content was determined using the method described by Haugh and Lantzsch (1993). Two (2) grams of each sample was extracted with $20 \mathrm{ml}$ of $2 \% \mathrm{HCl}$ for 3 hours. To $1 \mathrm{ml}$ of the extract was added $1 \mathrm{ml}$ of $0.3 \%$ ferric ammonium sulphate solution in a test tube and stoppered. The mixture was then boiled for $30 \mathrm{~min}$ in 
water bath. The tube was cooled in ice for $15 \mathrm{~min}$ and allowed to adjust to room temperature. The contents of the test tubes were then centrifuged at $3000 \mathrm{rpm}$ for $30 \mathrm{~min}$. One millilitre $(1.0 \mathrm{ml})$ of the supernatant was mixed with $1.5 \mathrm{ml}$ of $0.02 \mathrm{M} \mathrm{2,} 2$ dipyridine solution and the absorbance was read at 519nm against a blank (distilled water) in a spectrophotometer (Atomic Absorption Spectrophotometer -AAS Model SP9). Phytate will be expressed in percentage and calculated as shown below.

$\%$ Phytate $=\frac{a u}{a s} \times \frac{C}{W} \times \frac{V f}{V a} \times \frac{100}{1}$

Where: $\quad \mathrm{au}=$ Absorbance of test sample, as $=$ Absorbance of standard solution, $\mathrm{C}=$ Concentration of standard solution, $\mathrm{W}=$ Weight of sample used, $\mathrm{Vf}=$ Total volume of extract, $\mathrm{Va}=$ Volume of extract used

Oxalate: This was carried out according to AOAC (2005). Two (2) grams of each sample was extracted thrice at $50^{\circ} \mathrm{C}$, stirred for 1 hour with $20 \mathrm{ml}$ of $0.3 \mathrm{~N} \mathrm{HCl}$. The combined extract was diluted (made up) to $100 \mathrm{ml}$ with distilled water and used for total oxalate estimation. The oxalate was estimated by pipetting about $5 \mathrm{ml}$ of the extract which was made alkaline with $1 \mathrm{ml}$ of $5 \mathrm{~N}$ ammonium hydroxide. About 3 drops of phenolphthalein was added to the extract and acetic acid was added in drops. Also about $1 \mathrm{ml}$ of $5 \%$ aqueous calcium chloride was then added to the mixture and allowed to stand for 2 hours after which it was centrifuged at $3000 \mathrm{rpm}$ for 15 minutes. The supernatants were discarded and the precipitates washed three times with hot water, thoroughly mixed and centrifuged each time. In the test tube, $2 \mathrm{ml}$ of $3 \mathrm{~N} \mathrm{H}_{2} \mathrm{SO}_{4}$ was added and the precipitate was dissolved by warming in water bath at $75^{\circ} \mathrm{C}$. The content of the test tube was then titrated with freshly prepared $0.01 \mathrm{~N}$ $\mathrm{KMnO}_{4}$ at room temperature until the first pink colour appeared throughout the solution. This was then warmed at $75^{\circ} \mathrm{C}$ and the titration continued until the pink colour persisted. This experiment was carried out in triplicates. $\%$ Oxalate $=\frac{V t}{W} x$ Vme $x$ Titre $x 100$

Where: $\quad \mathrm{Vt}=$ total volume of titrate $=100$

$\mathrm{Ws}=$ weight of the sample $=2 \mathrm{~g}$

$\mathrm{Vme}=$ volume - mass equivalent (i.e. $1 \mathrm{~cm}^{3}$ of $0.05 \mathrm{M} \mathrm{kMn0}_{4}$ is equivalent to $0.00225 \mathrm{~g}$ anhydrous oxalic acid)

Haemagglutinin: This was determined using the spectrophotometric method of Arntfield et al. (1985). Half of a gram of each sample was mixed with phosphate buffer solution $(50 \mathrm{ml})$ and filtered to obtain the extract used in the analysis. An aliquot $(1 \mathrm{ml})$ of the extract from each sample was added to a test tube containing $9 \mathrm{ml}$ of suspended trypsinated rabbit red blood cells. A control test tube contained the suspended cells but without extract. The tubes were allowed to stand at room temperature for 10mins before their respective absorbances were measured in a spectrophotometer (Atomic Absorption Spectrophotometer - AAS Model SP9) of 510nm wavelength. The experiment was carried out in triplicates. The amount of agglutinin in the test sample was expressed as the number of units of agglutinin observed per gram of the test sample.

$$
\mathrm{HUI} / \mathrm{g}=\frac{1}{W} x(a u-a s) x \frac{V f}{V a}
$$

Where: $\quad \mathrm{HUI} / \mathrm{g}=$ Haemagglutinin units per gram, $\mathrm{W}=$ Weight of sample used, $\mathrm{au}=$ Absorbance of test sample, as $=$ Absorbance of standard sample, $\mathrm{Vf}=$ Total extract volume, $\mathrm{Va}=$ Volume of extract used

Trypsin Inhibitor: This was done using the spectrophotometric method described by Armtfield et al. (1985). Five (5) grams of each sample was dispersed in $50 \mathrm{ml}$ of $0.5 \mathrm{M} \mathrm{NaCl}$ solution and stirred for 30 minutes at room temperature. It was centrifuged and the supernatant filtered through Whatman No. 42 filter paper. The filtrate was used for the assay. Standard trypsin wasprepared and used to treat the substrate solution (N-benzol-D1arginine-p-anilide, BAPA). The extent of inhibition was used as a standard for measuring the trypsin. In the tube containing $2 \mathrm{ml}$ of extract, $10 \mathrm{ml}$ of the substrate (BAPA) was added. Also, the second part of the standard trypsin solution was added in another test tube containing only $10 \mathrm{ml}$ of the substrate. The latter served as the blank. The content of the tubes were allowed to stand for 30 minutes and then the absorbances of the solution were measured spectrophotometrically (Atomic Absorption Spectrophotometer - AAS Model SP9) at 410nm wavelength. One trypsin activity unit inhibited is given by an increase on 0.01 absorbance unit at $410 \mathrm{~nm}$. The experiment was carried out in triplicates.

Where: $\quad \mathrm{au}=$ Absorbance of test sample

Trypsin unit inhibited $/ 100 \mathrm{~g}=\frac{a u}{a s} \times 0.01 \times F$

as $=$ Absorbance of standard sample

$$
\mathrm{F}=\text { Experimental factor is given as } \frac{V f}{V a} \times \frac{1}{w}
$$

Where: $\quad \mathrm{Vf}=$ Total Volume of extract

$\mathrm{Va}=$ Volume extract analyzed

$\mathrm{W}=$ Weight of sample analyzed

\section{VITAMIN ANALYSIS}

The vitamin (Vitamin A, Vitamin C (Ascorbic acid, Vitamin B (Thiamine), Vitamin $\mathrm{B}_{2}$ (Riboflavin), Vitamin $\mathrm{B}_{3}$ (Niacin)) contents of the samples was carried out by the method as described by AOAC (2005) 


\section{Results And Discussion}

Vitamin Contents of Pigeon Pea Flour Samples Processed By Different Methods

The results of the vitamins contents of the pigeon pea flour samples are shown in Table 1. The vitamin A contents ranged from $0.011-0.077 \mathrm{ug} / 100 \mathrm{~g}$. There were significant differences $(\mathrm{p}<0.05)$ in the vitamin A contents of the pigeon pea flours, with the sprouted/fermented sample $\left(\mathrm{S}_{\mathrm{o}} \mathrm{S}_{\mathrm{p}} \mathrm{FPPF}\right)$ having the highest vitamin $\mathrm{A}$ content $(0.077 \mu \mathrm{g} / 100 \mathrm{~g})$ and this was significantly higher than those of samples $\mathrm{S}_{\mathrm{o}} \mathrm{S}_{\mathrm{p}} \mathrm{PPF}(0.051 \mu \mathrm{g} / 100 \mathrm{~g})$ and $\mathrm{S}_{0}$ FPPF $(0.045 \mathrm{ug} / 100 \mathrm{~g})$ at $5 \%$ level of significance. The lowest vitamin A content $(0.011 \mu \mathrm{g} / 100 \mathrm{~g})$ was recorded for sample $\mathrm{S}_{\mathrm{o}} \mathrm{BPPF}$ and this value was significantly $(\mathrm{p}<0.05)$ lower than those of the control $\left(\mathrm{S}_{\mathrm{o}} \mathrm{PPF}\right)$ and the other boiled samples.

The result showed that sprouting, fermentation and combined sprouting/fermentation processes led to increase in the vitamin A content of the pigeon pea flours. This increase in might be due to synthesis of vitamin A by increased activities of hydrolytic enzymes and fermenting microorganisms. Boiling of the pigeon pea before conversion to flour decreased the vitamin A content of the flour. This decrease may be due to leaching of vitamin A into the boiling water. The result is in agreement with the report of Walters et al. (1993) and Fadahunsi (2009) who stated that boiling leads to decrease in vitamins while fermentation leads to increase in vitamin of bambara groundnut. Shah et al. (2011) reported that sprouting increases vitamin A content of legumes. Olanipekun et al. (2015) equally observed that boiling reduced the vitamin content of kidney bean flour.

There were significant differences $(\mathrm{p}<0.05)$ in the vitamin $\mathrm{C}$ (ascorbic acid) contents of the pigeon pea flour samples. The vitamin $C$ contents of the flour samples ranged from $0.945-13.82 \mathrm{mg} / 100 \mathrm{~g}$. The highest vitamin $\mathrm{C}$ value $(13.820 \mathrm{mg} / 100 \mathrm{~g})$ was observed in sample $\mathrm{S}_{\mathrm{o}} \mathrm{S}_{\mathrm{p}} \mathrm{FPPF}$, followed by sample $\mathrm{S}_{\mathrm{o}} \mathrm{S}_{\mathrm{p}} \mathrm{PPF}(12.820$ $\mathrm{mg} / 100 \mathrm{~g})$ and $\mathrm{S}_{0} \mathrm{FPPF}(8.630 \mathrm{mg} / 100 \mathrm{~g})$. The lowest vitamin $\mathrm{C}$ content $(0.945 \mathrm{mg} / 100 \mathrm{~g})$ was recorded in sample $\mathrm{S}_{0} \mathrm{BPPF}$ followed by the control sample ( $\left.\mathrm{S}_{0} \mathrm{PPF}\right)$ and the other boiled samples. This increase could be due to synthesis of vitamin $\mathrm{C}$ by the hydrolytic activities of enzymes and activities of microorganisms during sprouting and fermentation respectively. And the decrease may be due to leaching of the vitamin into the boiling water. Fadahunsi (2009) reported that fermentation led to increase of vitamin in bambara groundnut. Shah et al. (2011) observed that sprouting increased vitamin C (antioxidant vitamin) of legumes. Uherova et al. (1993) reported that boiling caused a high loss of ascorbic acid in vegetables. Sangronis and Machado (2005) stated that germination

Table 3: Vitamin Contents of Pigeon Pea Flour Samples Processed By Different Methods

\begin{tabular}{|c|c|c|c|c|c|}
\hline Flour sample & $\begin{array}{l}\text { Vitamin A } \\
\mu \mathrm{g} / \mathbf{1 0 0 g} \\
\end{array}$ & $\begin{array}{l}\text { Vitamin C } \\
\text { (Ascorbic acid) } \\
\text { mg/100g }\end{array}$ & $\begin{array}{l}\text { Vitamin } B_{1} \\
\text { (Thiamine) } \\
\text { mg/100g }\end{array}$ & $\begin{array}{l}\text { Vitamin } B_{2} \\
\text { (Riboflavin) } \\
\text { mg/100g }\end{array}$ & $\begin{array}{l}\text { VitaminB } \\
\text { (Niacin) } \\
\text { mg/100g } \\
\end{array}$ \\
\hline $\mathrm{S}_{0} \mathrm{PPF}$ & $0.038 \pm 0.001^{\mathrm{e}}$ & $2.515 \pm 0.02^{\mathrm{g}}$ & $0.730 \pm 0.01^{\mathrm{d}}$ & $0.145 \pm 0.01^{\mathrm{d}}$ & $2.920 \pm 0.03^{\mathrm{d}}$ \\
\hline$S_{0} B P P F$ & $0.011 \pm 0.001^{\mathrm{h}}$ & $0.945 \pm 0.02^{\mathrm{h}}$ & $0.270 \pm 0.01^{\mathrm{h}}$ & $0.045 \pm 0.04^{\mathrm{f}}$ & $1.615 \pm 0.02^{\mathrm{h}}$ \\
\hline $\mathrm{S}_{0}$ FPPF & $0.045 \pm 0.001^{\mathrm{c}}$ & $8.630 \pm 0.04^{\mathrm{c}}$ & $0.920 \pm 0.01^{\mathrm{c}}$ & $0.505 \pm 0.02^{\mathrm{c}}$ & $4.915 \pm 0.03^{\mathrm{c}}$ \\
\hline $\mathrm{S}_{\mathrm{o}} \mathrm{BFPPF}$ & $0.022 \pm 0.001^{\mathrm{g}}$ & $3.115 \pm 0.02^{\mathrm{f}}$ & $0.335 \pm 0.02^{\mathrm{g}}$ & $0.115 \pm 0.02^{\mathrm{e}}$ & $2.325 \pm 0.04^{\mathrm{g}}$ \\
\hline $\mathrm{S}_{\mathrm{o}} \mathrm{S}_{\mathrm{p}} \mathrm{PPF}$ & $0.051 \pm 0.002^{\mathrm{b}}$ & $12.820 \pm 0.03^{\mathrm{b}}$ & $0.965 \pm 0.02^{\mathrm{b}}$ & $0.565 \pm 0.01^{\mathrm{b}}$ & $5.795 \pm 0.02^{\mathrm{b}}$ \\
\hline $\mathrm{S}_{\mathrm{o}} \mathrm{S}_{\mathrm{p}} \mathrm{BPPF}$ & $0.031 \pm 0.0^{\mathrm{f}}$ & $4.710 \pm 0.01^{\mathrm{e}}$ & $0.380 \pm 0.0^{f}$ & $0.135 \pm 0.02^{\mathrm{de}}$ & $2.510 \pm 0.01^{\mathrm{f}}$ \\
\hline $\mathrm{S}_{\mathrm{o}} \mathrm{S}_{\mathrm{p}} \mathrm{FPPF}$ & $0.077 \pm 0.002^{\mathrm{a}}$ & $13.820 \pm 0.03^{\mathrm{a}}$ & $1.165 \pm 0.02^{\mathrm{a}}$ & $0.665 \pm 0.02^{\mathrm{a}}$ & $6.510 \pm 0.01^{\mathrm{a}}$ \\
\hline $\mathrm{S}_{\mathrm{o}} \mathrm{S}_{\mathrm{p}} \mathrm{BFPPF}$ & $0.043+0.002^{\mathrm{d}}$ & $4.820 \pm 0.03^{\mathrm{d}}$ & $0.420 \pm 0.03^{\mathrm{e}}$ & $0.135 \pm 0.02^{\mathrm{de}}$ & $2.640 \pm 0.01^{\mathrm{e}}$ \\
\hline LSD $(p<0.05)$ & 0.0013 & 0.027 & 0.019 & 0.0245 & 0.023 \\
\hline
\end{tabular}

Values are means \pm Standard deviations from the means. Means with different letter within a column are significantly different $(\mathrm{p}<0.05)$. LSD $=$ Least significant difference

Key:

$\mathrm{S}_{\mathrm{O}} \mathrm{PPF}=$ soaked pigeon pea flour (control)

$\mathrm{S}_{0} \mathrm{BPPF}=$ soaked and boiled pigeon pea flour

$\mathrm{S}_{\mathrm{O}} \mathrm{FPPF}=$ soaked and fermented pigeon pea flour

$\mathrm{S}_{\mathrm{O}} \mathrm{BFPPF}=$ soaked, boiled and fermented pigeon pea flour

$\mathrm{S}_{\mathrm{o}} \mathrm{S}_{\mathrm{p}} \mathrm{PPF}=$ soaked and sprouted pigeon pea flour

$\mathrm{S}_{\mathrm{O}} \mathrm{S}_{\mathrm{p}} \mathrm{BPPF}=$ soaked, sprouted and boiled pigeon pea flour

$\mathrm{S}_{\mathrm{O}} \mathrm{S}_{\mathrm{P}} \mathrm{FPPF}=$ soaked, sprouted and fermented pigeon pea flour

$\mathrm{S}_{\mathrm{o}} \mathrm{S}_{\mathrm{p}} \mathrm{BFPPF}=$ soaked, sprouted, boiled and fermented pigeon pea flour

Increased ascorbic acid of pigeon pea by $208.4 \%$. Satya et al. (2010) explained that during sprouting process, biosynthesis of vitamin $\mathrm{C}$ takes place. Vitamin $\mathrm{C}$ (Ascorbic acid) is an antioxidant vitamin which helps to scavenge free radicals in the cells. Vitamin $\mathrm{C}$ is very vital in iron metabolism and subsequent fight against iron deficiency anaemia (Manoranja and Sood, 2010). Olanipekun et al. (2011) also reported that vitamins A and $\mathrm{C}$ being antioxidants help to fight diseases like cancer and diabetes and also help to slow down the natural 
aging process. Therefore combined use of sprouting/fermentation in the processing of pigeon pea flour raised the vitamin $C$ content of the flour from 2.515 to $13.820 \mathrm{mg} / 100 \mathrm{~g}$ which is $449.50 \%$ increase.

There were significant differences $(\mathrm{p}<0.05)$ in the vitamin $\mathrm{B}_{1}$ (thiamine) contents of the pigeon pea flours and these ranged from $0.270-1.165 \mathrm{mg} / 100 \mathrm{~g}$. The highest vitamin $B_{1}$ value $(1.165 \mathrm{mg} / 100 \mathrm{~g})$ was recorded in sample $S_{0} S_{p}$ FPPF followed by samples $S_{0} S_{p} P P F(0.965 \mathrm{mg} / 100 \mathrm{~g})$ and $\mathrm{S}_{0} F P P F(0.920 \mathrm{mg} / 100 \mathrm{~g})$ and these were significantly different $(\mathrm{p}<0.05)$ from one another in vitamin $\mathrm{B}_{1}$ content. The control sample recorded vitamin $B_{1}$ value of $0.730 \mathrm{mg} / 100 \mathrm{~g}$, while the lowest value $(0.270 \mathrm{mg} / 100 \mathrm{~g})$ was observed in sample $\mathrm{S}_{0} B P P F$. There were significant differences $(\mathrm{p}<0.05)$ in vitamin $\mathrm{B}_{1}$ content of samples $\mathrm{S}_{\mathrm{o}} \mathrm{S}_{\mathrm{p}} \mathrm{BFPPF}(0.420 \mathrm{mg} / 100 \mathrm{~g})$, $\mathrm{S}_{\mathrm{o}} \mathrm{S}_{\mathrm{p}} \mathrm{BPPF}(0.380 \mathrm{mg} / 100 \mathrm{~g}), \mathrm{S}_{\mathrm{o}} \mathrm{BFPPF}(0.335 \mathrm{mg} / 100 \mathrm{~g})$ and $\mathrm{S}_{0} \mathrm{BPPF}(0.270 \mathrm{mg} / 100 \mathrm{~g})$. This result is in agreement with the report of Shah et al. (2011) who stated that vitamin $\mathrm{B}_{1}$ (thiamine) is increased by sprouting. There were significant differences $(\mathrm{p}<0.05)$ in the vitamin $\mathrm{B}_{2}$ (riboflavin) contents of pigeon pea flour samples. The highest vitamin $B_{2}$ content $(0.665 \mathrm{mg} / 100 \mathrm{~g})$ was recorded in sample $\mathrm{S}_{\mathrm{o}} \mathrm{S}_{\mathrm{p}} \mathrm{FPPF}$ followed by samples $\mathrm{S}_{\mathrm{o}} \mathrm{S}_{\mathrm{p}} \mathrm{PPF}(0.565 \mathrm{mg} / 100 \mathrm{~g})$ and $\mathrm{S}_{0} \mathrm{FPPF}(0.505 \mathrm{mg} / 100 \mathrm{~g})$ and these were significantly different $(\mathrm{p}<0.05)$ from each other. The control sample had a vitamin $B_{2}$ value of $0.145 \mathrm{mg} / 100 \mathrm{~g}$. The least vitamin $\mathrm{B}_{2}$ content $(0.045$ $\mathrm{mg} / 100 \mathrm{~g})$ was observed in sample $\mathrm{S}_{0} \mathrm{BPPF}$ and this was also significantly different $(\mathrm{p}<0.05)$ from samples $\mathrm{S}_{\mathrm{o}} \mathrm{BFPPF}(0.045 \mathrm{mg} / 100 \mathrm{~g}), \mathrm{S}_{\mathrm{o}} \mathrm{S}_{\mathrm{p}} \mathrm{BPPF}(0.135 \mathrm{mg} / 100 \mathrm{~g})$ and $\mathrm{S}_{\mathrm{o}} \mathrm{S}_{\mathrm{p}} \mathrm{BFPPF}(0.135 \mathrm{mg} / 100 \mathrm{~g})$.Uherova et al. (1993) maintained that conventional cooking caused a high loss of thiamine, riboflavin and ascorbic acid in vegetables as they are highly soluble in water. Riboflavin (vitamin $\mathrm{B}_{2}$ ) plays a critical role in the body energy production.

There were significant differences $(\mathrm{p}<0.05)$ in the vitamin $\mathrm{B}_{3}$ (niacin) contents of pigeon pea flour samples. The highest vitamin $B_{3}$ content $(6.510 \mathrm{mg} / 100 \mathrm{~g})$ was recorded in sample $\mathrm{S}_{\mathrm{o}} \mathrm{S}_{\mathrm{p}} \mathrm{FPPF}$ followed by sample $\mathrm{S}_{\mathrm{o}} \mathrm{S}_{\mathrm{p}} \mathrm{PPF}(5.795 \mathrm{mg} / 100 \mathrm{~g})$ and $\mathrm{S}_{\mathrm{o}} \mathrm{FPPF}(4.915 \mathrm{mg} / 100 \mathrm{~g})$. The lowest vitamin $\mathrm{B}_{3}$ content $(1.615 \mathrm{mg} / 100 \mathrm{~g})$ was observed in sample $S_{0} B P P F$. The control sample had a vitamin $B_{3}$ content of $2.920 \mathrm{mg} / 100 \mathrm{~g}$. There were significant differences $(\mathrm{p}<0.05)$ in the vitamin $B_{3}$ contents of samples $S_{0} B F P P F(2.325 \mathrm{mg} / 100 \mathrm{~g}), \mathrm{S}_{0} \mathrm{~S}_{\mathrm{p}} \mathrm{BPPF}$ $(2.510 \mathrm{mg} / 100 \mathrm{~g})$ and $\mathrm{S}_{\mathrm{o}} \mathrm{S}_{\mathrm{p}} \mathrm{BFPPF}(2.640 \mathrm{mg} / 100 \mathrm{~g})$. The results are in agreement with the reports that boiling leads to decrease in the vitamins while fermentation leads to increase in vitamin of Bambara groundnut (Walters et al., 1993; Fadahunsi, 2009). Amany et al. (2014) reported that germination of chickpea caused an increase in vitamin $\mathrm{B}_{3}$ content at the level of $36.50 \%$. Niacin (vitamin $\mathrm{B}_{3}$ ) (nicotinic acid and nicotinamide) facilitates lipid catabolism and plays a key role in tricarboxylic acid cycle.

\section{Anti-nutrients Content of Pigeon Pea Flour Samples Processed By Different Methods}

The anti-nutrient contents of the pigeon pea flour samples processed with different methods are shown in Table 2. The saponin contents of the pigeon pea flour samples were reduced by each of the processing methods (boiling, fermentation, sprouting) and were reduced too much lower levels by the combination of boiling, sprouting and fermentation processes (Table 2). The control sample $\left(\mathrm{S}_{0} \mathrm{PPF}\right)$ had the highest saponin value $(2.97 \mathrm{mg} / 100 \mathrm{~g})$ followed by the soaked/boiled sample, $\mathrm{S}_{\mathrm{o}} \mathrm{BPPF}$ which hada value of $2.15 \mathrm{mg} / 100 \mathrm{~g}$. There were significant differences $(\mathrm{p}<0.05)$ among the saponin contents of almost all the flour samples with the exception of the soaked/fermented, the soaked/sprouted, the soaked/boiled/fermented and soaked/sprouted/boiled pigeon pea flour samples which had similar values. The reduction in saponin due to sprouting would probably have been caused by enzymatic hydrolysis while that due to fermentation was due to microbial degradation. And that due to boiling would have been caused by leaching of the saponins into the boiling water.Processing techniques such as boiling, sprouting and fermentation had been noted to reduce antinutritional contents of legume flours (Trugo et al. 1990; Henry and Massey, 2001; Edema and Sanni, 2006).

There were also significant differences $(\mathrm{p}<0.05)$ in the phytic acid contents of the pigeon pea floursamples with the exception of the samples $S_{0} B F P P F(1.10 \mathrm{mg} / 100 \mathrm{~g}), S_{0} S_{p} B P P F(1.04 \mathrm{mg} / 100 \mathrm{~g}), S_{0} F P P F$ $(1.90 \mathrm{mg} / 100 \mathrm{~g})$ and $\mathrm{S}_{\mathrm{o}} \mathrm{S}_{\mathrm{p}} \mathrm{PPF}(1.82 \mathrm{mg} / 100 \mathrm{~g})$ which had no significant differences $(\mathrm{p}<0.05)$. The control sample (SoPPF) had the highest value of phytic acid $(5.76 \mathrm{mg} / 100 \mathrm{~g})$. Boiling of the soaked pigeon pea reduced the phytic acid content of the flour by more than $50 \%(2.76 \mathrm{mg} / 100 \mathrm{~g})$. The combined soaking, sprouting, boiling and fermentation processes reduced the phytic acid to the lowest value of $0.22 \mathrm{mg} / 100 \mathrm{~g}$, and this value was significantly $(\mathrm{p}<0.05)$ lower than the phytic acid content $(0.53 \mathrm{mg} / 100 \mathrm{~g})$ obtained for the soaked/sprouted/fermented flour sample $\left(\mathrm{S}_{\mathrm{o}} \mathrm{S}_{\mathrm{p}} \mathrm{FPPF}\right)$. Boiling also contributed in the reduction due to degradation of the phytic acid by the heat of the boiling water. Reduction in phytic acid has also been reported by Adeniran et al. (2013) in lima bean seeds and locust bean seeds after fermentation. Esonu et al. (1998) and Egli et al. (2002) also noted that phytic acid was hydrolysed during sprouting of legume seeds. Reduction of phytic acid during sprouting and fermentation could be due to enzymatic action which increased the level of phytase to cause a decrease in phytic acid. 
Table 2: Anti- nutrients Content of Pigeon Pea Flour Samples Processed By Different Methods

\begin{tabular}{|c|c|c|c|c|c|c|c|c|}
\hline $\begin{array}{l}\text { Flour } \\
\text { sample }\end{array}$ & $\begin{array}{l}\text { Saponin } \\
\mathrm{mg} / 100 \mathrm{~g}\end{array}$ & $\begin{array}{l}\text { Phytic acid } \\
\mathrm{mg} / 100 \mathrm{~g}\end{array}$ & $\begin{array}{l}\text { Oxalate } \\
\mathrm{mg} / 100 \mathrm{~g}\end{array}$ & $\begin{array}{l}\text { Alkaloids } \\
\mathrm{mg} / 100 \mathrm{~g}\end{array}$ & $\begin{array}{l}\text { Cyanide } \\
\mathrm{mg} / 100 \mathrm{~g}\end{array}$ & $\begin{array}{l}\text { Trypsin } \\
\text { Inhibitor } \\
\text { TIU/100g }\end{array}$ & $\begin{array}{l}\text { Haemagglutinin } \\
\mathrm{mg} / 100 \mathrm{~g}\end{array}$ & $\begin{array}{l}\text { Tannin } \\
\mathrm{mg} / 100 \mathrm{~g}\end{array}$ \\
\hline $\mathrm{S}_{0} \mathrm{PPF}$ & $2.97 \pm 0.02^{\mathrm{a}}$ & $5.76+0.02^{\mathrm{a}}$ & $3.44+0.02^{\mathrm{a}}$ & $6.97 \pm 0.02^{\mathrm{a}}$ & $2.30+0.01^{\mathrm{a}}$ & $10.27+0.02^{\mathrm{a}}$ & $8.22+0.03^{\mathrm{a}}$ & $1.03+0.02^{\mathrm{a}}$ \\
\hline $\mathrm{S}_{0} \mathrm{BPPF}$ & $2.15+0.02^{b}$ & $2.79+0.02^{b}$ & $1.98+0.01^{b}$ & $2.92+0.03^{b}$ & $0.93+0.01^{b}$ & $4.77+0.04^{b}$ & $3.10 \pm 0.01^{b}$ & $0.83+0.01^{\mathrm{b}}$ \\
\hline $\mathrm{S}_{0}$ FPPF & $1.17+0.01^{c}$ & $1.90+0.01^{c}$ & $1.22+0.01^{\mathrm{d}}$ & $1.92 \pm 0.01^{\mathrm{d}}$ & $0.32 \pm 0.03^{c}$ & $3.59 \pm 0.03^{c}$ & $2.41 \pm 0.01^{c}$ & $0.74 \pm 0.02^{\mathrm{d}}$ \\
\hline $\mathrm{S}_{0} \mathrm{BFPPF}$ & $0.82+0.01^{d}$ & $1.10+0.01^{d}$ & $0.87+0.01^{\mathrm{e}}$ & $1.26+0.02^{\mathrm{a}}$ & $0.10+0.01^{\mathrm{e}}$ & $1.27+0.01^{\mathrm{e}}$ & $1.13+0.03^{f}$ & $0.34+0.01^{f}$ \\
\hline $\mathrm{S}_{0} \mathrm{~S}_{p} \mathrm{PPF}$ & $1.14 \pm 0.02^{c}$ & $1.82 \pm 0.01^{c}$ & $1.53+0.02^{c}$ & $2.09+0.02^{c}$ & $0.17 \pm 0.01^{\mathrm{d}}$ & $2.08+0.02^{\mathrm{d}}$ & $2.11+0.02^{\mathrm{d}}$ & $0.78+0.01^{c}$ \\
\hline $\mathrm{S}_{0} \mathrm{~S}_{p}$ BPPF & $0.85 \pm 0.0^{\mathrm{d}}$ & $1.04 \pm 0.01^{\mathrm{d}}$ & $0.92+0.02^{\mathrm{e}}$ & $0.92+0.01^{f}$ & $0.08+0.01^{f}$ & $1.10 \pm 0.01^{f}$ & $1.25 \pm 0.0^{\mathrm{e}}$ & $0.41 \pm 0.01^{\mathrm{e}}$ \\
\hline $\mathrm{S}_{0} \mathrm{~S}_{\mathrm{p}} \mathrm{FPPF}$ & $0.58+0.02^{2}$ & $0.53+0.0^{\mathrm{e}}$ & $0.22+0.02^{f}$ & $0.22+0.01^{\mathrm{g}}$ & $0.03+0.002^{\mathrm{g}}$ & $0.67+0.02^{\mathrm{g}}$ & $0.92+0.01^{\mathrm{g}}$ & $0.30+0.01^{\mathrm{g}}$ \\
\hline $\mathrm{S}_{0} \mathrm{~S}_{p}$ BFPPF & $0.39 \pm 0.01^{f}$ & $0.22+0.02^{\mathrm{f}}$ & $0.04+0.002^{\mathrm{g}}$ & $0.05 \pm 0.0^{\mathrm{h}}$ & $0.01 \pm 0.001^{\mathrm{h}}$ & $0.14+0.0^{\mathrm{h}}$ & $0.45 \pm 0.03^{\mathrm{h}}$ & $0.17 \pm 0.0^{\mathrm{h}}$ \\
\hline $\begin{array}{l}\text { LSD } \\
(p<0.05)\end{array}$ & 0.173 & 0.164 & 0.017 & 0.018 & 0.015 & 0.023 & 0.021 & 0.015 \\
\hline
\end{tabular}

Values are means. \pm Standard deviations from the means. Means with different letter within a column are significantly different $(\mathrm{P}<0.05)$. $\mathrm{LSD}=$ Least significant difference

Key: $S_{0} P P F=$ soaked pigeon pea flour $($ control $), S_{0} B P P F=$ soaked and boiled pigeon pea flour, $S_{0} F P P F=$ soaked and fermented pigeon pea flour, $S_{0} B F P P F=$ soaked, boiled and fermented pigeon pea flour, $S_{0} S_{p} P P F=$ soaked and sprouted pigeon pea flour, $S_{0} S_{p} B P P F=$ soaked, sprouted and boiled pigeon pea flour, $S_{0} S_{p} F P P F=$ soaked, sprouted and fermented pigeon pea flour, $\mathrm{S}_{\mathrm{o}} \mathrm{S}_{\mathrm{p}} \mathrm{BFPPF}=$ soaked, sprouted, boiled and fermented pigeon pea flour

There were significant differences $(\mathrm{p}<0.05)$ in the oxalate contents of the pigeon pea flour samples with the exception of the samples $S_{0} B F P P F(0.87 \mathrm{mg} / 100 \mathrm{~g})$ and $S_{0} S_{p} B P P F(0.92 \mathrm{mg} / 100 \mathrm{~g})$ where there was no significant difference $(\mathrm{p}<0.05)$. The highest oxalate content $(3.44 \mathrm{mg} / 100 \mathrm{~g})$ was recorded in the control sample $\left(\mathrm{S}_{\mathrm{o}} \mathrm{PPF}\right.$ ) followed by sample $\mathrm{S}_{\mathrm{o}} \mathrm{BPPF}$ witha value of $1.98 \mathrm{mg} / 100 \mathrm{~g}$. Samples $\mathrm{S}_{\mathrm{o}} \mathrm{FPPF}$ and $\mathrm{S}_{\mathrm{o}} \mathrm{S}_{\mathrm{p}} \mathrm{PPF}$ had oxalate contents of $1.22 \mathrm{mg} / 100 \mathrm{~g}$ and $1.53 \mathrm{mg} / 100 \mathrm{~g}$ respectively. The lowest oxalate content $(0.04 \mathrm{mg} / 100 \mathrm{~g})$ was recorded in the flour sample that was soaked/sprouted/boiled and fermented $\left(\mathrm{S}_{\mathrm{o}} \mathrm{S}_{\mathrm{p}} \mathrm{BFPPF}\right)$ and the second lowest oxalate value $(0.22 \mathrm{mg} / 100 \mathrm{~g})$ was recorded in the flour sample $S_{\mathrm{o}} S_{\mathrm{p}}$ FPPF. This result is in agreement with the report of El-Moneim et al. (2012) who stated that soaking, boiling, sprouting and fermentation reduced levels of oxalate in sorghum. This result corroborates with the findings of Henry and Massey (2001) and Nwosu et al. (2013) who indicated a decrease in oxalate content of pigeon pea seed as a result of malting treatment.

There were significant differences $(\mathrm{p}<0.05)$ in the alkaloid contents of the pigeon pea flour samples. The control sample $\left(\mathrm{S}_{\mathrm{o}} \mathrm{PPF}\right)$ had the highest alkaloid content $(6.97 \mathrm{mg} / 100 \mathrm{~g})$ followed by sample $\mathrm{S}_{\mathrm{o}} \mathrm{BPPF}$ $(1.98 \mathrm{mg} / 100 \mathrm{~g})$. Sample $\mathrm{S}_{\mathrm{o}} \mathrm{FPPF}$ had an alkaloid value of $1.92 \mathrm{mg} / 100 \mathrm{~g}$, which was significantly different $(p<0.05)$ from those of samples $S_{0} B F P P F(1.26 \mathrm{mg} / 100 \mathrm{~g})$ and $S_{\mathrm{o}} S_{\mathrm{p}} P P F(2.09 \mathrm{mg} / 100 \mathrm{~g})$. The reduction of alkaloids due to boiling, sprouting and fermentation had been reported respectively by Farris and Singh (1990), Livernais-Saettel (2002) and Edema and Sanni (2006). Udedibie and Nwaiwu (1988) had earlier reported that cooking for 60 minutes eliminated alkaloid in jack beans

There were significant differences $(\mathrm{p}<0.05)$ in the cyanide contents of some of the pigeon pea flour samples. The highest cyanide content $(2.30 \mathrm{mg} / 100 \mathrm{~g})$ was recorded in the control sample $\left(\mathrm{S}_{0} \mathrm{PPF}\right)$ and that was significantly higher $(\mathrm{p}<0.05)$ than the values of samples $\mathrm{S}_{\mathrm{o}}$ BPPF $(0.93 \mathrm{mg} / 100 \mathrm{~g}), \mathrm{S}_{\mathrm{o}} \mathrm{FPPF}(0.32 \mathrm{mg} / 100 \mathrm{~g})$, $\mathrm{S}_{\mathrm{o}} \mathrm{S}_{\mathrm{p}} \mathrm{PPF}(0.17 \mathrm{mg} / 100 \mathrm{~g})$ and the other samples.It has been reported that boiling (Farris and Singh, 1990; Carlini and Udedibie, 1997; Balogun et al., 2001), sprouting (Henry and Massey, 2001; Livernaise-Seattel, 2002) and fermentation (Barimalaa et al., 1994; Edema and Sanni, 2006) processes reduce cyanide content of legumes.

There were significant differences $(\mathrm{p}<0.05)$ in the trypsin inhibitor contents of the pigeon pea floursamples. The control flour sample $\left(\mathrm{S}_{\mathrm{o}} \mathrm{PPF}\right)$ had the highest trypsin inhibitor content (10.27TIU/100g) followed by the soaked/boiled flour sample(4.77TIU/100g) and soaked/fermented flour sample (3.59TIU/100g). The reduction was highest in the flour sample which was processed by the combined processing methods (sprouting/boiling/fermentation, $\left.\mathrm{S}_{\mathrm{o}} \mathrm{S}_{\mathrm{p}} \mathrm{BFPPF}\right)(0.14 \mathrm{TIU} / 100 \mathrm{~g})$, followed by the soaked/sprouted/fermented flour sample, $S_{0} S_{p}$ FPPF $(0.67 T I U / 100 g)$. The reduction in the levels of trypsin inhibitor are in agreement with the results of other workers who reported that boiling (Farris and Singh, 1990; Carlini and Udedibie, 1997; Balogun et al., 2001), sprouting (Khan et al., 1991; Henry and Massey, 2001) and fermentation (Edema and Sanni, 2006; El-Moneim et al., 2012) are able to decrease trypsin inhibitor activity.

There were significant differences $(\mathrm{p}<0.05)$ in the haemagglutinin contents of the pigeon pea flour samples. The highest haemagglutinin content $(8.22 \mathrm{mg} / 100 \mathrm{~g})$ was recorded for the control sample $\left(\mathrm{S}_{\mathrm{o}} \mathrm{PPF}\right)$, followed by sample $S_{0}$ BPPF $(3.10 \mathrm{mg} / 100 \mathrm{~g})$ and sample $S_{0}$ FPPF $(2.41 \mathrm{mg} / 100 \mathrm{~g})$. The lowest haemagglutinin content $(0.45 \mathrm{mg} / 100 \mathrm{~g})$ was recorded for sample $S_{\mathrm{o}} S_{\mathrm{p}}$ BFPPF followed by sample $S_{\mathrm{o}} S_{\mathrm{p}} \mathrm{FPPF}(0.92 \mathrm{mg} / 100 \mathrm{~g})$ and sample $S_{o} S_{p} B P P F(1.25 \mathrm{mg} / 100 \mathrm{~g})$. There were significant differences $(\mathrm{p}<0.05)$ in the tannin contents of all the samples of pigeon pea flourstudied. The highest tannin content $(1.03 \mathrm{mg} / 100 \mathrm{~g})$ was recorded for the control flour 
sample $\left(\mathrm{S}_{\mathrm{o}} \mathrm{PPF}\right)$ and that was significantly higher $(\mathrm{p}<0.05)$ than that of sample $\mathrm{S}_{0} \mathrm{BPPF}(0.83 \mathrm{mg} / 100 \mathrm{~g})$. The decrease in tannin content is in agreement with the findings of Obizoba and Atti (1991) and Adeparasi (1994).

\section{Conclusion}

The increments in vitamins have shown the quality that can be obtained from combined sprouted/fermented pigeon pea flour. This was shown in the increased vitamin $\mathrm{A}, \mathrm{C}, \mathrm{B}_{1}, \mathrm{~B}_{2}$, and $\mathrm{B}_{3}$. The decreased anti-nutrients by combined sprouting/fermentation processing method might have contributed to the increments in vitamins. It is therefore recommended as the best method for eliminating anti-nutritional factors in pigeon pea.

\section{References}

[1]. Adeniran, H. A., Farinde, E. O. and Obatolu, V. A. (2013). Effect of Heat Treatment and Fermentation on Anti-nutrients Content of Lima Bean (PhaseolusLunatus) During Production of Daddewa Analogue. Annual Review and Research in Biology 3 (3): 256-266.

[2]. Adeparasi, E. O. (1994). Evaluation of the nutririve potential of cooked pigeon pea (Cajanus cajan) meal as a plant protein source for clearias gariepinus fingerlings. Journal of Agric. Tech. 2(1): 48-57.

[3]. Akande, K. E. and Fabiyi, E. F. (2010). Effect of Processing Methods on some Antinutritional Factors in Legume Seeds for Poultry Feeding. Intl. Journal of Poultry Sci. 9(10): 996-1001.

[4]. Akporhonor, E. E., Egwaikhide, P. A. and Eguavoen, I. O. (2006). Effect of Sprouting on in vitro digestibility of some locally consumed leguminous seeds. Journal of Appl. Sci. and Environ. Management 10(3): 55-58.

[5]. Amany, A. S., El-Bostany, A. N., Samia, A. A. and Hala, A. T. (2014). Effect of domestic processing methods of some legumes on phytochemicals contents and in intro bioavailability of some minerals. J. Of American Sci. 10: 12.

[6]. AOAC (2005). Official Methods Of Analysis International $18^{\text {th }}$ Edition. Association of Official Analytical Chemists, USA

[7]. Arntfield, S. D., Ismond, M. A. H. and Murray, E. D. (1985). The fate of antinutritional factors during the preparation of Faba bean protein isolate using micellization technique. Canadian Institiute of Food Sci. and Technol. J. 18: 137-143.

[8]. Barimalaa, I. S., Achinewhu, S. C., Yiutara, I. and Amedi, E. N. (1994). Studies on the solid substrate fermentation of bambara groundnut. Science of Food Agriculture, 66: 443-453.

[9]. Blumberg, J. (1995). Role of Vitamins in Health Promotion and the Prevention of non communicable diseases (Background paper prepared for the joint WHO/FAO Consultation on the preparation and use of Food-based Dietary Guidelines), Nicosia, Cyprus. March, 1995.

[10]. Bradbury, J. H., Egan, S. V. and Lynch, M. J. (1985). Analysis of cyanide in cassava using the hydrolysis of cyanogenic glycosides. Journal of Sci. Food and Agric. 55: 177-290.

[11]. Carlini, C. R. and Udedibie, A. B.I. (1997). Comparative effects of processing methods on haemagglutinating and antitryptic activities of Canavaliaensiformis and Canavalia braziliensis seeds. J. Agric. Food Chem. 45: 4372-4377.

[12]. Chavan, J. K. and Kadam, S. S. (1989). Nutritional improvement of cereals by sprouting. Critical Reviews on Food Science and Nutrition 28(5): 401-437

[13]. Edema, M. O. and Sanni, A. (2006). Microorganisms population of fermenting maize meal for sour maize bread production in Nigeria. Niger J. Microbiol. 20(2): 937-946.

[14]. Egli, I., Davidson, L., Juilleret, M. A., Barclay, O. and Hurrell, R. (2002). The influence of soaking and germination on the phytase activity and phytic acid content of grains and seeds potentially useful for complementary feeding. J. Food Sci. 67: 3484-3488

[15]. El-Moneim, A., Afify, M. R., El-Beltagi, H. S., Samiha, M. A., El-Salam and Omran, A. A. (2012). Protein Solubility, Digestibility and Fractionation after Germination of Sorghum Varieties. Research Article Editor: Vladmir

[16]. Enwere, J. N. (1998). Foods of Plant Origin. Afro Orbis Publ. Ltd. Nsukka Nigeria. Pp. 64-124.

[17]. Esonu, B. O., Udedibie, A. B. I. and Carlini, C. R. (1998). The effect of toasting, dry urea treatment and sprouting on some thermostable toxic factors in the jack bean seed. Nig. J. Anim. Prod. 25: 36-39.

[18]. Fadahunsi, I. F. (2009). The Effect of Soaking, Boiling, and Fermentation with Rhizopus oligosporus on the Water Soluble Vitamin Content of Bambara Groundnut. Pakistan Journal of Nutrition 8: 835-840.

[19]. Farris, D. G. and Singh, U. (1990). Pigeon pea nutrition and products. In: Y. L. Nene et al.The Pigeon pea. Petencheru A. P. 502324, India ICRISAT pp. 467.

[20]. Harborne, J. B. (1973). Photochemical Analysis. A Guide to Modern Techniques in Plant Analysis. Chapman and Hall, New York.

[21]. Haugh, W. and Lantzsch, H. J. (1993). Sensitive method for determination of phytate in cereals and cereal product. Plant Foods for Human Nutrition 44: 261-266.

[22]. Henry, C. J. K. and Massey, D. (2001). Micronutrient Changes during food processing and storage. Crops Post Harvest Programme (CPHP) - Issue paper, 5 December 2011.

[23]. Holmes, R. P. and Kennedy, M. (2003). Estimation of the oxalate content and daily intake. Kidney Int. 57: 1662-1667.

[24]. James, C. S. (1995). The Analytical Chemistry of Foods. Chapman and Hall, New York.

[25]. Janardharan, K., Gurumoorthi, P. and Pugalenthi, M. (2003). Nutritional potential of five accessions of a South Indian tribe pulse, Mucuna pruriens var utilis. I. The effect of processing methods on the content of I-doppa, phytic acid and oligosaccharides. J. Trop. Subtrop. Agrosystems 1: 141-152.

[26]. Khan, N., Zaman, R. and Elahi, M. (1991). Effect of heat treatment on the phytic acid content of maize plants. J. Sci. Food Agric. 54: $153-156$

[27]. Liener, J. E. (1994). Anti nutritional factors. In: Legume Chemistry, Technology and Human Nutrition Matthews, R. H. (ed). Marcel Daker Inc. New York. Pp. 339-382.

[28]. Livernais-Saettel, L. (2002). www.dietobio.com/effects.html. Accessed on September 10, 2014.

[29]. Manoranja, K. and Sood, S. (2010). Food Preservation and Processing. Kalyami Publishers, New Delhj. Pp. 28-30

[30]. Nwosu, J. N., Ojukwu, M., Ogueke, C. C., Ahaotu, I. and Owuamanam, C. I. (2013). The Antinutritional Properties and Ease of Dehulling on the proximate Composition of pigeon pea (Cajanus cajan) as affected by Malting. Int. J. Life Sciences, vol. 2, No. 2 pp. 60-67.

[31]. Obizoba, I. C. and Atti, J. V. (1991). Effect of Soaking, Sprouting, Fermentation and cooking on the nutrient composition and some anti-nutritional factors of sorghum (Guinea) seeds. Plant Foods of Human Nutrition, 41: 203-212.

[32]. Okoye, Z. S. C. (1992). Biochemical Aspects of Nutrition. Prentice- Hall of India, New Delhi pp. 147-195. 
[33]. Olanipekun, O. T., Obatolu, V. A., Ejoh, S. I., Oyarekua, M. A. and Farinde, E. C. (2011). Evaluation of the nutrients and antinutrient contents of two Nigerian under-utilized legumes. Moor J. Agric. Res. 12: 56-63.

[34]. Olanipekun, O. T., Omenna, E. C., Olapade, O. A., Suleiman, P. and Omodara, O. G. (2015). Effect of boiling and roasting on the nutrient composition of kidney bean seed flour, Sky Journal of Food Science vol. 4(2): 024-029.

[35]. Oluwole, S. I. and Taiwo, R. E. (2009). Comparison of nutritional composition and anti-nutrient status of fermented, germinated and roasted Bambara groundnut seeds (Vigna subterranean). British Food Journal 3(4): 376-386

[36]. Price, M. L., Vanscoynoe, S. and Butler, L. G. (1987). A Critical evaluation of the vanillin reaction as an essay for tannis in sorghum grain. J. Agric. Food Chem. 26: 1214-1218.

[37]. Sangronis, E. and Machado, C. J. (2005). Influence of germination on the nutritional quality of Phaseolus vulgaris and Cajanus cajan. www.sciencedirect.com. Accessed on $20^{\text {th }}$ June, 2016.

[38]. Sathe, S. K. and Solunkhe, D. K. (1984). Technology of removal of unwanted components of dry beans. CRC Crit. Rev. Food Sci. Nutr. 21: 263-287.

[39]. Satya, S., Kaushik, G. and Naik, N. (2010). Processing of food legumes: a boom to human nutrition. Meditterr. J. Nutr. Metab. 3: 183-195.

[40]. Shah, S. A., Zeb, A., Masood, T., Noreen, N., Abbas, S. U., Samiulla, M., Alim, M. A. and Muhammad, A. (2011). Effects of Sprouting time on biochemical and nutritional qualities of Mungbean varieties. African Journal of Agricultural Research Vol. 6(22): 5091-5098.

[41]. Sharma, A., Jood, S. and Saghal, S. (1996). Anti-nutrients (Phytic acid, polyphenols) and minerals (Ca, Fe) availability (in-vitro) of chickpea and lentil cultivars. Nahrung, 40: 182-184

[42]. Trugo, L. C., Ramos, L. A., Trugo, N. M. F. and Souza, M. C. P. (1990). Oligosaccharide composition and trypsin inhibitor activity of Phaseolus vulgaris and the effect of fermination on the alpha-galactoside composition and fermentation in the human colon. Food Chemistry 36: 53-61.

[43]. Udedibie, A. B. I. and Nwaiwu, J. (1988). The potential of jackbean (Canavalia ensiformis) as animal feed. Nig. Agric. J., 23: 130143 .

[44]. Ugwu,F. M. (2008). Comparative assessment of the nutritional quality and acceptability of germinated and fermented flours from some minor legumes. Ph.D Thesis University Published. Enugu State University of Technology, Enugu State.

[45]. Uherova, R., Hozova, B. and Sminov, V. (1993). The effect of microwave heating on retention of some B-vitamins. Food Chem., 46: $293-295$

[46]. UNICEF (United Nations Children Emergency Fund) (1996). Child Nutrition. New York, USA. Published for UNICEF by Oxford Universities Press. P. 82

[47]. USDA, (2009). National Nutrient Database for Standard Reference. http://www.nal.usda.gov/finic. Accessed, August 10, 2016.

[48]. Uzogara, S. G., Morton, I. D. and Daniel, J. W. (1992). Changes in some antinutrients of cowpea (Vigna unguiculata) processed with alkaline salt. Plant Foods Hum. Nutr., 4: 249-258.

[49]. Walters, K. H., Chinnan, M. S., Hung, Y. C. and Branch, A. L. (1993). Effect of predecortication, drying temperature on cowpea paste, characteristics and functionalityin preparation of Akara. Cereal Chemistry 65: 23-27. 